\title{
Correction to: The Sources of Political Normativity: the Case for Instrumental and Epistemic Normativity in Political Realism
}

\section{Carlo Burelli $^{1}$ (D) Chiara Destri ${ }^{2}$ (D)}

Published online: 29 November 2021

(c) Springer Nature B.V. 2021

\section{Correction to: Ethical Theory and Moral Practice https://doi.org/10.1007/s10677-021-10243-y}

The original version of the article unfortunately contained some typos.

The original article has been corrected.

Publisher's Note Springer Nature remains neutral with regard to jurisdictional claims in published maps and institutional affiliations.

The original article can be found online at https://doi.org/10.1007/s10677-021-10243-y.

\section{Carlo Burelli}

carlo.burellu@edu.unige.it

Chiara Destri

chiara.destri@sciencespo.fr

1 University of Genova, Genova, Italy

2 Sciences Po, Paris, France 